\title{
New Research on Discourses of Childhood
}

\author{
Marja Sorvari
}

Marja Sorvari is an assistant professor of Russian language and culture at the University of Eastern Finland, Joensuu Campus. Her current research interests include children and childhoods in post-Soviet contexts, multilingual literature, and border studies. She has published book chapters and journal articles on autobiographical studies and feminist and gender studies in Russian literature and culture. Her recent publications include articles on how childhood is imagined and remembered in post-Soviet (autobiographical) fiction. Email: marja.sorvari@uef.fi

\section{Book Review: Childhood, Literature, and Science: Fragile Subjects}

Jutta Ahlbeck, Päivi Lappalainen, Kati Launis, and Kirsi Tuohela, editors London and New York: Routledge, 2018 260pp.

ISBN: 9781138282407

Children and childhoods are the object of a variety of academic disciplines, from medical and social sciences to historical and literary studies. Countless studies explore childhood and children in education, health care, the welfare state, politics, media, culture, and so on. But how do cultural representations and scientific discourses meet in their ways of portraying children? This is one of the questions that the editors, Finnish scholars Jutta Ahlbeck, Päivi Lappalainen, Kati Launis, and Kirsi Tuohela, put forward in Childhood, Literature, and Science. The task the editors and 13 researchers from various disciplines set out to fulfill is to study the concepts of childhood and the child as discursive constructions in Western modernity.

The volume consists of the editors' introduction and 16 chapters divided into five parts investigating child figures-"notions, constructs, representations, discourses, memories" (p. 7) -in the fields of cultural imagination, autobiographies and life-writings, as well as scientific discourses and expert knowledge on children. The key theoretical concept and analytical tool of the volume, the child figure, is a "fragile subject," as Ahlbeck, Lappalainen, Launis, and Tuohela note in their introduction: it is portrayed "in need of intervention, guidance, and protection" (p. 7) and it is disciplined by different power relations associated with gender, class, and race. Part I, titled "The Ideal and Subversive Child," delves into the norms and ideals set by societies on children and childhood at different times and shows how different, even opposing, perceptions of children and childhood have been brought up in children's literature. Päivi Lappalainen demonstrates how the child figure is seen as becoming a citizen of a nation-state to serve and find its rightful place in society in the $19^{\text {th }}$-century Finnish writer Zacharias Topelius's works for children, Läsning för barn. According to Lappalainen, this becoming was entangled with a gender bias: in Topelius's stories boy figures were allowed more freedom and were more active than girl figures. By contrast, Maria Laakso's article discusses how in the early $20^{\text {th }}$ century the Finnish writer Jalmari Finne's humorous and popular books for children on the Kiljunen family represent "burlesque anarchy" (p. 39) and naughty children who undermine the adult world's norms. In Finne's books, both boys and girls behave badly, "which, according to Laakso, makes the humor even more subversive" (p. 42). Finne's books on the Kiljunen family thus represent a break with the Topelian tradition in Finnish children's literature. In Jenniliisa Salminen's article on the Soviet Russian author Lazar Lagin's novel The Old Man Hottabych (1955/1992), the roles of the child and adult seem to have changed places: paradoxically, the adult figure is imperfect whereas the child figure is perfect. The character old man Hottabych is a genie released by a schoolboy named Volka. When the genie wants to reward his liberator, it turns out that "no magic makes a positive impression on Soviet children, because in their world, everything is already perfect" (p. 49). 
In Part II "the 'normal' child" is scrutinized in three chapters discussing the rise of child sciences, especially the theories of mind and psyche from the late 1800 s to the $20^{\text {th }}$ century. In her chapter, Kati Launis argues that narrative fiction of the late $19^{\text {th }}$ century offered early ideas of the child's mind. The child was a "mystery" (p. 61) that was scrutinized by artists and scientists alike. In Finland, the realist writers Juhani Aho, Minna Canth, and Teuvo Pakkala offered in their works representations of the modern child, and especially of girlhood. It is notable that these writers were aware of the contemporary psychological and pedagogical studies. Launis argues that "at the turn of the century, the mystery of childhood was discussed at the same time by scientists and writers, in different countries" (p. 69). Karin Zetterqvist Nelson's article discusses the child figure in Swedish child psychotherapy literature during 1945-1975. In this literature, the figure of the child was understood to be "at constant risk of being disturbed in its developmental psychological processes" (p. 81). Therefore, the professional child therapist was at centre stage interpreting the "inner drama" (p. 82) of the child. The chapter by Shaul Bar-Haim discusses two important scholars of interwar child psychoanalysis, Anna Freud and Melanie Klein, and the child figure in their thinking. Bar-Haim notes that Anna Freud, along with Sigmund Freud and Sandor Ferenczi, considered the psyche as a developmental whole (an infant becomes a child, then an adolescent, and finally an adult), which stressed the concepts of process and growth. By contrast, Melanie Klein's concept of "position" does not differentiate between a child's and an adult's mind, but instead "some major dimensions of the childish mind are always there from the beginning, essentially non-developed and resilient to any change” (p. 93). A similar idea-although with no reference to Klein's work-on the co-presence of the child in the adult mind, comes up again in the discussion of literary works in Saara Jäntti's article on women's madness narratives, as will be noted below.

Part III “The Sick and Disabled Child” contains four intriguing articles on representations of children with illnesses or disabled children. The articles convey ways of representing emotions and empathy through various media. Maria Nikolajeva's article discusses young adult fiction from the viewpoint of cognitive poetics and argues that fiction representing experiences of disabled children may potentially increase understanding of this experience among able-bodied youth. Letitia Fernández-Fontecha Rumeu's chapter shows how photographs of sick children shaped the way the sick child was perceived in Victorian society: the photographs not only gave greater visibility to sick children, but also emphasized the role of medical practitioners in managing children's health and diseases and created emotional affect. As the author argues, "photography is a fruitful way to penetrate the embodied emotional experiences of the past" (p. 125). Karen Lowton in her chapter investigates how children with severe liver disease, who could potentially survive through liver transplantation during the 1980s-1990s, coped with their experiences and how they were portrayed through various texts and images. The data includes, for example, interviews with the now-adult patients and survivors. Lowton notes that the case of liver transplantation shows "the intertwining of science, medicine, policy and media with the public imagination of what can become possible" (p. 138). The fourth chapter in this part brings us back to the investigation of young adult fiction. Sarah Hardstaff explores the figures of the "sick young adult," the "working young adult," and the "young adult caregiver" in two texts: Mildred Taylor's The Road to Memphis (1990) and Cynthia Voigt's Seventeen Against the Dealer (1989). Both novels picture illness as a means to bring to the fore social themes and ideas, especially barriers to professional medical care, and the role of informal care and love. Hardstaff argues that "neither informal ('love') nor formal ('expert') care are sufficient for recuperation on their own-both must be in place" (p. 143). The fictional constructions of the failure of formal care bring to the fore ethical questions about healthcare provision.

Part VI "The Evil and Victimized Child" discusses child figures who transgress boundaries of normality and how they were perceived by their contemporaries. Eleanor F. W. Betts discusses press representations of children who had committed a willful murder and shows that these representations employed existing scripts to make deviant deeds more comprehensible in Victorian England. The investigation shows that towards the end of the $19^{\text {th }}$ century the imaginary changed; as child psychology contributed to a different understanding of child psyche, press 
representations started emphasizing some damage experienced by the child who murdered, instead of describing them as monsters. In her chapter, Jutta Ahlbeck notes that the figure of the nervous child became an emblem of the emerging nation-state at the turn of the $20^{\text {th }}$ century in Finland. This figure was both classed and gendered; nervousness was seen as essentially feminine and a threat to the social order. On the other hand, it was women who, as mothers, had the "potential of 'saving' the nation from nervousness and further degeneration" (p. 180). Ahlbeck's chapter forms an interesting parallel with Päivi Lappalainen's chapter on child figures and nation building in children's literature in Finland (see above). Although there are notable differences between the child figures, it is interesting how gender forms a constant element in this discourse. Child figures reflect anxieties also in $21^{\text {st }}$ century Poland, when babies conceived through in vitro fertilization (IVF) are perceived either as "monsters" or "innocent babies" (p. 185) in mass media representations. Ewa Maciejewska-Mroczek and Magdalena RadkowskaWalkowicz argue that IVF children are used as "rhetorical figures, metaphors or disembodied symbols" (p. 192) appearing in two opposite discourses: the discourse of fear and the discourse of hope. There is no space for the "actual experience of children and their families" (p. 193) in these two opposing views.

Part V “The Lost Child” explores women's autobiographical constructions of childhood and the figure of the child ranging from early $19^{\text {th }}$-century Finnish autobiographies to $1990 s^{\prime}$ women's madness narratives and $21^{\text {st }}$-century neoliberal parenting culture. Kirsi Tuohela argues convincingly that in the early-19 $9^{\text {th }}$-century autobiographies written by Fredrika Lindqvist and Fredrika Runeberg, childhood played a central role in the "tracing and creating" (p. 208) of the autobiographer's personal human interiority, because it was the space where the concept of "heart" was seeded, and "heart" was the key to the truth of the inner "I." Roberta Garrett, on the other hand, shows the public "mothershaming" (p. 211) that two autobiographical books, Amy Chua's memoir Battle Hymn of the Tiger Mother and Julie Myerson's The Lost Child, received in media. The two books, according to Garrett, show how the neoliberal model of mothering is intensely child centered but also promotes "intense parental competitiveness" (p. 222), which are incompatible philosophies. The figures of child and mother are combined in Saara Jäntti’s chapter on women's madness narratives, which discusses, among others, Lauren Slater's Prozac Diary (1998) and Bessie Head's A Question of Power (1974). In these autobiographical madness narratives, the mad protagonists, contrary to the understanding of psychiatry, do not blame their mad mothers or childhood for their mental illness, but "illness becomes a way to identify with them [mad mothers]" (p. 227). It seems that the mother-child dyad is a source of vulnerability for both: Being a mother of a child may cause mental disturbances, as well as being a child of a mad mother. However, as Jäntti argues, the child can also pull their mother out of madness. Garrett's and Jäntti's chapters suggest that it is necessary to think about how to promote shared parenting instead of an individual model of controlling, caring, and cultivating mothering.

As we can see, Childhood, Literature, and Science brings different understandings and approaches into dialogue and offers a compelling study on how the figure of the child and childhood talk to us about our understanding of modernity and subjectivity. It is noteworthy that the chapters represent a multitude of various cultural and linguistic contexts (e.g., Nordic, East European, English, American, Asian American) of childhood studies. Thus, it would have been interesting to read reflections on differences and similarities between, for instance, concepts of childhood in Finnish and (Soviet) Russian children's literature, or between media representations of children in English and Polish contexts. In this respect, a summarizing concluding chapter discussing the theoretical and empirical insights of the individual chapters and parts would have been useful. In addition, a summary could have opened novel perspectives on the intercultural understanding of children and childhoods. Nevertheless, the reader can find interesting parallels and transformations of how child figures and childhoods have been used as discursive constructs by comparing the chapters and their findings. For example, the volume offers fruitful parallel discussions on how children's literature and children's writers have worked in different social and cultural contexts and created un/suitable child characters, and on how young adult fiction can serve as an important means for 
young people to learn empathy and tolerance and see how damaging inequality can be. From an interdisciplinary perspective, the volume is a unique blend of literary, cultural, sociological, and psychological research on the child figure and childhood. The chapters bring to the fore many links between literature, media, and psychological theories and how they nourish each other in childhood studies. The abundance of themes, materials, and theories, as well as the detailed analyses of literary figures, media representations, and scientific discourses in Childhood, Literature, and Science make this volume of utmost importance to those who want to have a better understanding of the discursivity and cultural constructedness of childhoods and children in Western modernity. 


\section{References}

Ahlbeck, J., Lappalainen, P., Launis, K., \& Tuohela, K. (Eds.). (2018). Childhood, literature, and science: Fragile subjects. London, UK: Routledge.

Chua, A. (2011). Battle hymn of the tiger mother. London, UK: Bloomsbury.

Head, B. (1974). A question of power. London, UK: Heinemann.

Lagin, L. (1992). Starik Hottabych. Moscow: Reteks. (Original work published 1955)

Myerson, J. (2009). The lost child. London, UK: Bloomsbury.

Slater, L. (1998). Prozac diary. New York, NY: Penguin Books.

Taylor, M.D. (1990). The road to Memphis. New York, NY: Penguin.

Topelius, Z. (1901/1903). Läsning för barn I-II. Barnlitteratur. Zacharias Topelius Skrifter. Retrieved from http://www.topelius.fi/index. php?docid=92

Voigt, C. (1989). Seventeen against the dealer. New York, NY: Atheneum Books. 